\title{
Hyperbilirubinemi hos nyfødte - et kontroversielt tema Erfaringer med nye indikasjoner for fototerapi og utskiftningstransfusjon
}

\author{
Alf Meberg \\ Barneavdelingen, Vestfold sentralsykehus, 3116 Tønsberg \\ Telefon: 33342000 Telefax: 33343947
}

\begin{abstract}
SAMMENDRAG
Nye indikasjoner for behandling av hyperbilirubinemi hos nyfødte (bilirubinskjema fra Hillingdon sykehus, England) ble innført ved Vestfold sentralsykehus primo 1994. Endringene i panoramaet av behandlingstiltak (lysbehandling, utskiftningstransfusjon) ble registrert $\mathrm{i}$ kohortene av levende fødte ved sykehuset $\mathrm{i}$ toårsperioden 1994-95 og sammenlignet med foregående treårsperiode 1991-93. Total lysbehandlingsprevalens falt signifikant fra 6,9\% av levende fødte i perioden 1991-93 til 5,5\% i perioden 1994-95 ( $<<0,005)$. Dette skyldtes helt et betydelig fall i prevalensen av fullbårne barn som ble lysbehandlet for fysiologisk ikterus, fra 4,3\% til 1,6\% i henholdsvis første og siste periode $(p<0,0005)$. Prevalensen av barn som ble behandlet for prematuritetshyperbilirubinemi steg signifikant fra 2,0\% av levende fødte til 3,2\% (p<0,0005). Dette var delvis forårsaket av en økning i prematuritetsinsidensen, som steg fra 4,5\% i perioden 1991-93 til 5,9\% i perioden 1994-95 $(\mathrm{p}<0,0005)$. Andelen premature som ble lysbehandlet steg fra $45,2 \%$ i første til $53,1 \%$ i siste periode $(p<0,05)$. Prevalensen av blodgruppeimmuniserte barn som ble lysbehandlet var uforandret $\mathrm{i}$ de to periodene (henholdsvis $0,6 \%$ og $0,7 \%)(p>0,05)$. Det var en markert reduksjon i prevalensen av barn som gjennomgikk utskiftningstransfusjon (fra 0,2 til $0,06 \%$ henholdsvis i de to periodene) $(\mathrm{p}<0,05)$. Mulighetene for uheldige psykologiske og biologiske effekter av lysbehandling til friske fullbårne barn med ikterus, reduseres relativt betydelig med de moderate justeringer av indikasjonene som er foretatt. Rutineskiftet har også betydd ressurssparing. På landsbasis vil en slik rutineendring medføre at 1000-2000 fullbårne barn hvert år kan unngå lysbehandling. Indikasjonene for fototerapi og utskiftningstransfusjon for hyperbilirubinemi hos nyfødte i Norge må diskuteres på nytt i lys av ny forskning med tanke på nasjonal konsensus. Kortere liggetider for nyfødte i sykehus etter fødselen gjør det nødvendig med gode rutiner for oppfølging av hyperbilirubinemi utenfor sykehus.
\end{abstract}

\section{Meberg A. Hyperbilirubinemia - a controversial topic. Experiences with new guidelines for phototherapy and exchange transfusion. Nor J Epidemiol 1997; 7 (1): 85-91.}

\section{ENGLISH SUMMARY}

New guidelines for treatment of hyperbilirubinemia in newborn infants (according to a bilirubin chart used at Hillingdon Hospital, England) were introduced at Vestfold Central Hospital primo 1994. Changes in the panorama of interventions (phototherapy, exchange transfusion) were recorded for the two-year period 1994-95 and compared to the preceding three-year period 1991-93. Total prevalence of infants treated by phototherapy declined from $6.9 \%$ among those born $1991-93$ to $5.5 \%$ in those born $1994-95(\mathrm{p}<0.005)$. This was entirely caused by a decline in the prevalence of term infants treated for physiological hyperbilirubinemia, from $4.3 \%$ in the cohort born $1991-93$ to $1.6 \%$ in the cohort born $1995-95(\mathrm{p}<0.0001)$. The prevalence of preterm infants (gestational age $<37$ weeks) treated by phototherapy increased from $2.0 \%$ to $3.2 \%$ respectively in the two periods $(\mathrm{p}<0.0005)$. This was partly caused by an increase in the preterm incidence from $4.5 \%$ of live born $1991-93$ to $5.9 \%$ among those born 1994-95 ( $\mathrm{p}<0.0005)$. The percentage of preterm infants treated by phototherapy increased from $45.2 \%$ to $53.1 \%$ respectively in the two periods $(\mathrm{p}<0.05)$. No significant change in the incidence of infants treated by phototherapy for blood group immunization occurred $(0.6 \%$ and $0.7 \%$ respectively for the two periods; $\mathrm{p}>0.05)$. The prevalence of infants treated by exchange transfusion decreased from $0.2 \% 1991-93$ to $0.06 \% 1994-95$ ( $p<$ 0.05 ). Psychological and biological side-effects from phototherapy in healthy term infants may have been reduced by the changes in guidelines undertaken. The change in therapeutic guidelines has also resulted in a save of resources. Applying these routines on a national base will avoid phototherapy in 1000-2000 term infants annually. Successively shorter stay of newborns in hospital after birth necessitates good routines for follow-up of hyperbilirubinemia after discharge. The guidelines for phototherapy and exchange transfusion for neonatal hyperbilirubinemia should be rediscussed to obtain a national consensus. 


\section{INNLEDNING}

Over $65 \%$ av fullbårne barn og nesten alle prematurt fødte utvikler ikterus de første dagene etter fødselen (1). Ikterus er derfor en normaltilstand hos nyfødte. Serum-bilirubinkonsentrasjonen kan imidlertid hos enkelte ellers friske fullbårne barn nå opp i nivåer som kan medføre kjerneikterus (> $600 \mu \mathrm{mol} / \mathrm{l})(2)$. For 40-50 siden var alvorlig ikterus en viktig årsak til perinatal død og permanente cerebrale skader. Dette opptrådte først og fremst ved hemolytisk sykdom forårsaket av blodgruppeimmunisering $(3,4)$. Erfaringer fra 1950-tallet bygget på barn med hemolytisk sykdom ble overført til friske fullbårne barn. Bilirubinnivåer skadelige for barn med blodgruppeimmunisering $(>342 \mu \mathrm{mol} / 1(20 \mathrm{mg} / 100 \mathrm{ml}))$ ble ansett å være potensielt toksiske også hos friske nyfødte uten hemolytisk sykdom $(3,5)$. Dette synet ble retningsgivende for behandling med utskiftningstransfusjon og senere for fototerapi ved fysiologisk ikterus (6).

Etablering av fototerapi for hyperbilirubinemi har medført at en relativt stor andel friske nyfødte får slik behandling (senere år trolig 5-10\% født ved norske sykehus). Lysbehandlingen har imidlertid i økende grad blitt kontroversiell i takt med økende erkjennelse av at fysiologisk ikterus er en normaltilstand forbundet med lav risiko for nevrologiske følgetilstander og andre komplikasjoner $(3,4,7,8)$. Tidlig nyfødtperiode er en "sensitiv periode" for psykologiske tilknytningsprosesser mellom mor og barn ("bonding") (9). All unødig sykeliggjøring og intervensjon må derfor begrenses til et minimum i denne tiden. I tillegg har lysbehandlingen en del biologiske bieffekter $(10,11)$ som gjør at unødig overbehandling bør unngås.

Med bakgrunn i ovenstående innførte vi ved Vestfold sentralsykehus primo 1994 nye indikasjoner for lysbehandling og utskiftningstransfusjon hos nyfødte med hyperbilirubinemi. Hensikten med denne artikkelen er å dokumentere endringene i panoramaet av behandlingstiltak med bakgrunn i dette rutineskiftet, og å diskutere disse i relasjon til nyere internasjonale synspunkter på behandling av hyperbilirubinemi hos nyfødte.

\section{MATERIALE OG METODER}

\section{Pasientmateriale}

Hos levende fødte barn ved Vestfold sentralsykehus i femårsperioden 1991-95 $(\mathrm{n}=11$ 600) ble det registrert antall barn som ble lysbehandlet (serumbilirubin over lysbehandlingsgrensen i henhold til gjeldende kriterier (se nedenfor)) for fysiologisk ikterus (gestasjonsalder $\geq 37$ uker, negativ Coombs' test), prematuritetsikterus (gestasjonsalder $<37$ uker, negativ Coombs' test) og for blodgruppeimmunisering (positiv Coombs' test). I tillegg ble barn behandlet for hyperbilirubinemi med utskiftningstransfusjon registrert.

\section{Bilirubinmålinger og kurver}

Ved utvikling av klinisk ikterus ble alle barn vurdert av lege fra barneavdelingen. Hvis barnets mor var blodgruppe 0 og/eller Rh-negativ ble det alltid først tatt blodprøve (navlestrengsblod ved Rh-negativitet hos mor) for måling av hemoglobin, bilirubin, blodtyping og Coombs' test. Hvis Coombs' test var positiv, hvis barnet ble lysbehandlet eller gjennomgikk utskiftningstransfusjon ble bilirubinnivået fulgt med blodprøver. Det samme gjalt prematurt fødte barn og fullbårne barn innlagt i neonatalenheten for overvåkning eller behandling av ulike tilstander. Screening for hyperbilirubinemi hos fullbårne barn med hvit hudfarge og fysiologisk ikterus ble i barselavdelingene utført ved hjelp av non-invasiv bilirubinmåling (transcutan bilirubin index) (Minola/Air-Shields ${ }^{\circledR}$ iktometer, Air-Shields Vickers, USA) (12) (figur 1). Non-invasiv bilirubinovervåkning ble brukt hvor mor var blodtype 0 og/eller Rh-negativ etter påvisning av negativ Coombs' test hos barnet (selv om ABOimmunisering ikke utelukkes ved negativ Coombs' test). Dersom transcutan bilirubin index overskred lysbehandlingsindikasjonen ble bilirubinnivået kontrollert i blodprøve. Resultatet av blodprøven avgjorde om lysbehandling ble startet eller ikke. Hos barn av ikke-kaukasisk rase ble bilirubinnivået målt ved blodprøvetagning, og non-invasiv screening ikke brukt.

I treårsperioden 1991-93 ble indikasjonene for lysbehandling og utskiftningstransfusjon stillet ut fra kriterier nedfelt $i$ et bilirubinskjema som har vært brukt ved de fleste norske barneavdelinger i en årrekke (Finne P, upubliserte data). Kriteriene er publisert av Bratlid (10). Skjemaet differensierer mellom tre grupper etter barnets fødselsvekt $(<1,5 \mathrm{~kg}, 1,5-2,5 \mathrm{~kg}$ og $>2,5 \mathrm{~kg}$ ), og forskjellige lysgrenser etter alder etter fødselen. For barn med fødselsvekt $>2,5 \mathrm{~kg}$ er indikasjonene for lysbehandling de tre første levedøgn henholdsvis serum-bilirubin $>175 \mu \mathrm{mol} / 1,>200$ $\mu \mathrm{mol} / \mathrm{l}$ og $>275 \mu \mathrm{mol} / \mathrm{l}$, og senere $>325 \mu \mathrm{mol} / \mathrm{l}$. For lavvektige barn er grensene satt lavere. Samme prinsipper gjelder for utskiftningstransfusjon. Med bakgrunn i egne undersøkelser over korrelasjonen mellom serum-bilirubinnivået og transcutan bilirubin index (13) var de korresponderende non-invasive verdiene innført i dette bilirubinskjemaet.

Fra 1. januar 1994 ble det skiftet til et engelsk bilirubinskjema (skjema brukt ved Hillingdon sykehus, England, modifisert etter Finlay og Tucker 1978 $(4,14)$ ) (figur 2). Dette skjemaet opererer med noe høyere verdier for serum-bilirubin som indikasjon for lysbehandling av fullbårne barn enn Finnes kriterier for barn med fødselsvekt $>2,5 \mathrm{~kg}$. Dette gjelder spesielt de første tre levedagene, men skjemaet opererer også med litt høyere verdier de følgende dagene $(>350 \mu \mathrm{mol} / \mathrm{l})$. For premature opererer skjemaet fra Hillingdon sykehus bare med én kurve, som er nært identisk med kurven for lysbehandling av barn med fødselsvekt $<1500 \mathrm{~g}$ etter Finnes kriterier 


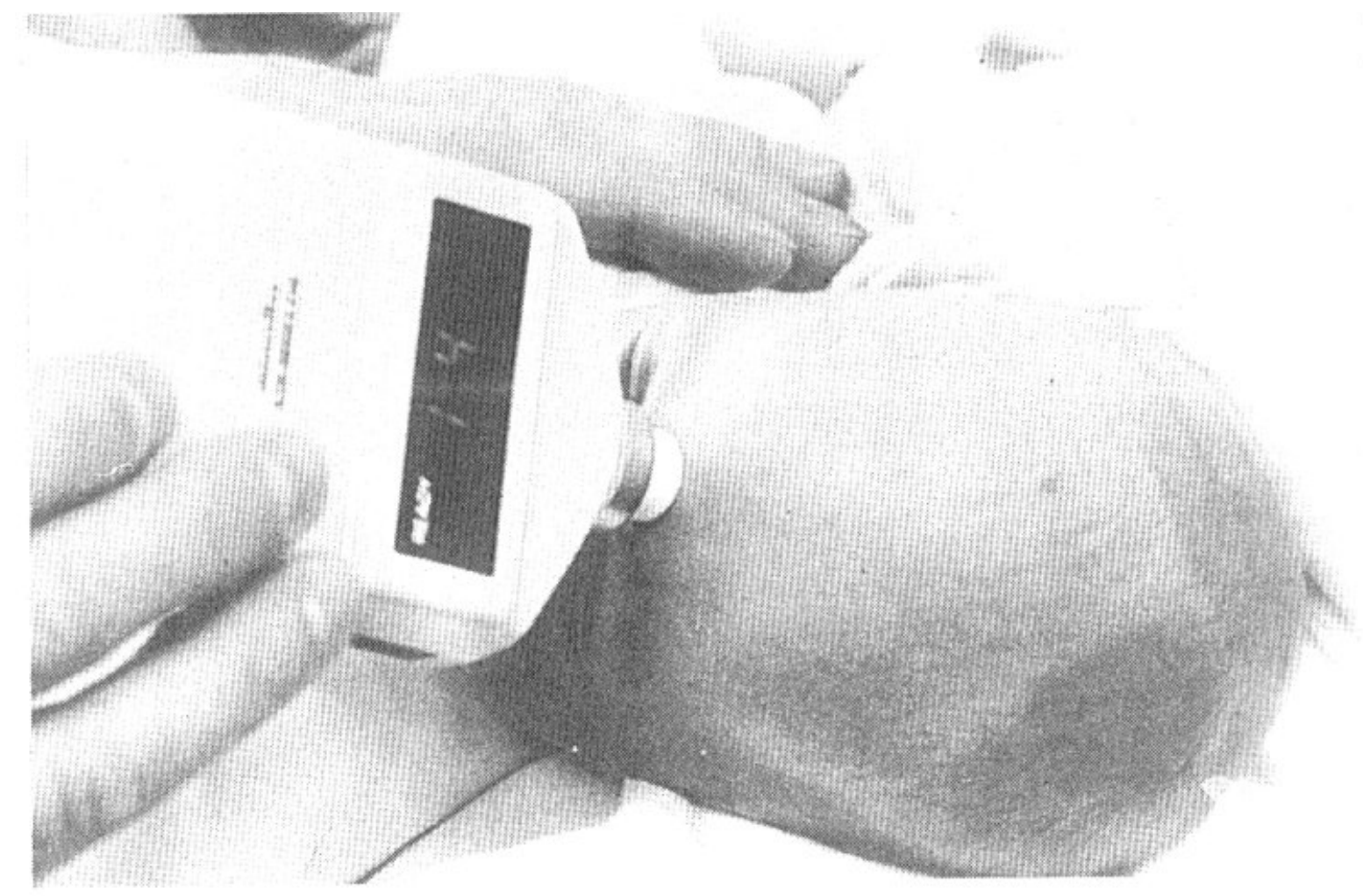

Figur 1. Non-invasiv bilirubinmåling.

de tre første levedager. De fire første levedager ligger bilirubinkurven for premature i Hillingdon-skjemaet godt under indikasjonsgrensen for lysbehandling av barn med fødselsvekt 1,5-2,5 kg etter Finnes kriterier, men er identisk fra og med femte levedag (serumbilirubin $>250 \mu \mathrm{mol} / 1)$. Dette medfører at flere premature vil ha bilirubinverdier over lysbehandlings grensen med det nye skjemaet fra Hillingdon sykehus enn etter våre tidligere anvendte kriterier. Bilirubinnivåene som indiserer utskiftningstransfusjon er også satt høyere både for premature og fullbårne i skjemaet fra Hillingdon sykehus. Skjemaet ble modifisert med innføring av korresponderende non-invasive bilirubin index verdier.

De nye retningslinjene for behandling av hyperbilirubinemi ble gjenstand for forelesninger $i$ kurssammenheng (primærhelsetjenesten, helsestasjonspersonell, internt i sykehuset), skriftlig informasjonsmateriell ble utarbeidet og distribuert gjennom egne utsendelser og publisert i lokal fagpresse.

\section{Statistiske metoder}

$\mathrm{X}^{2}$-test ble anvendt for å analysere forskjeller mellom kohortene av barn født $\mathrm{i}$ de to tidsperiodene 1991-93 og 1994-95. En p-verdi $<0,05$ ble ansett som statistisk signifikant.

\section{RESUltater}

Tabell 1 viser data for barn født $\mathrm{i}$ de to periodene 1991-93 og 1994-95 med hensyn til fødselstall, bruk av lysbehandling og utskiftningstransfusjon. Total lysbehandlingsprevalens falt signifikant fra $6,9 \%$ av levende fødte $\mathrm{i}$ første periode til 5,5\% i siste $(\mathrm{p}<$ $0,005)$. Dette skyldtes helt et betydelig fall i prevalensen av fullbårne barn som ble lysbehandlet for fysiologisk ikterus, fra 4,3\% til 1,6\% i henholdsvis første og siste periode $(\mathrm{p}<0,0005)$. Prevalensen av barn som ble behandlet for prematuritetshyperbilirubinemi steg signifikant fra $2,0 \%$ av levende fødte til $3,2 \%(\mathrm{p}<0,0005)$. Dette var delvis forårsaket av en økning i prematuritetsinsidensen (gestasjonsalder < 37 uker), som steg fra 4,5\% i perioden 1991-93 til $5,9 \%$ i perioden $1994-95$ ( $\mathrm{p}<0,0005)$. Andelen premature som ble lysbehandlet steg fra $45,2 \%$ i første til $53,1 \%$ i siste periode $(\mathrm{p}<0,05)$. Prevalensen av blodgruppeimmuniserte barn som ble lysbehandlet var uforandret $\mathrm{i}$ de to periodene (henholdsvis $0,6 \%$ og $0,7 \%)(p>0,05)$. Det var en betydelig reduksjon $\mathrm{i}$ prevalensen av barn som gjennomgikk utskiftningstransfusjon (fra 0,2 til $0,06 \%$ henholdsvis $\mathrm{i}$ de to periodene) $(p<0,05)$.

Figur 3 viser den prosentvise andelen av levendefødte som ble lysbehandlet hvert år i perioden 1991- 


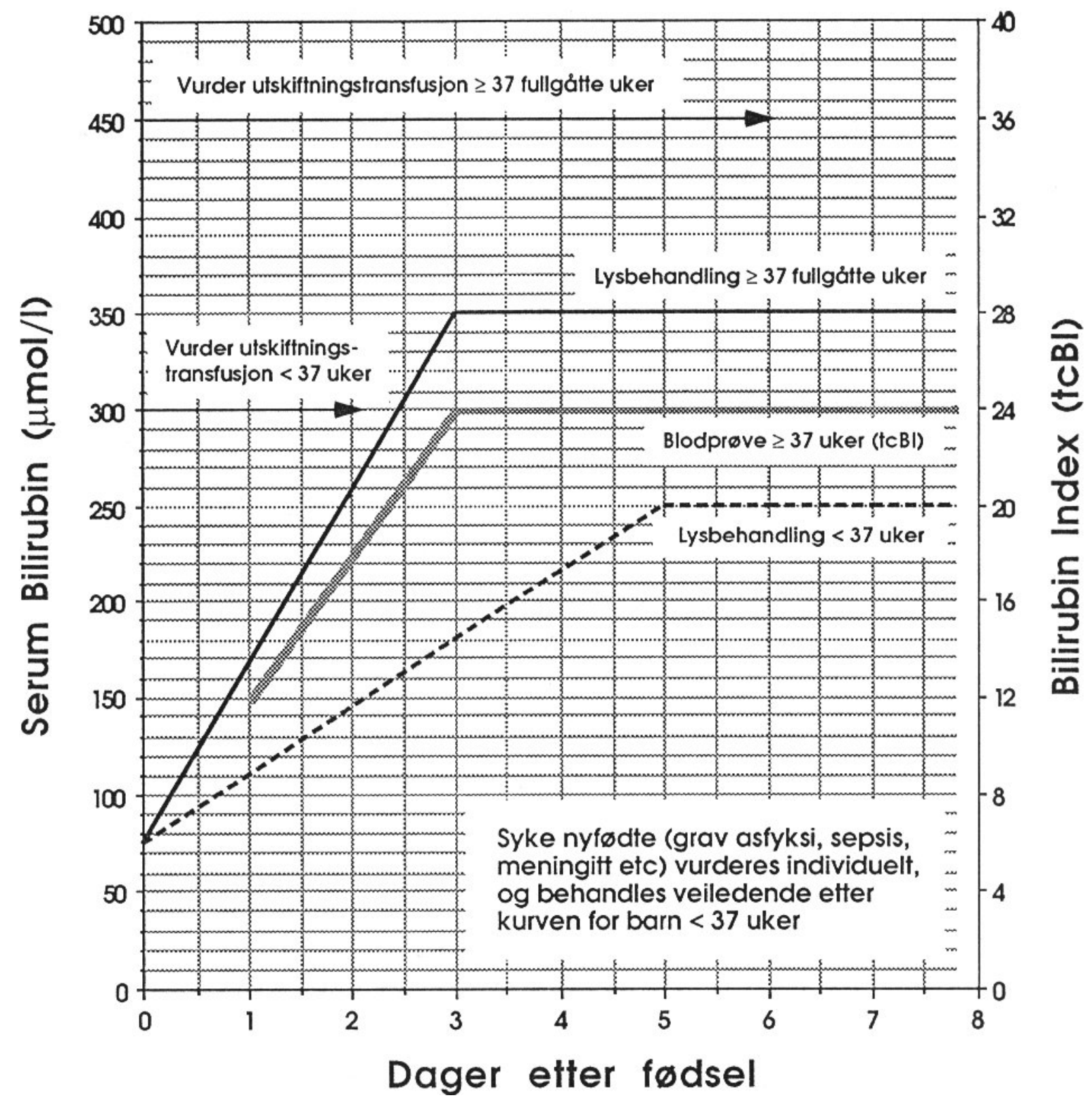

Figur 2. Indikasjoner for lysbehandling og utskiftningstransfusjon for hyperbilirubinemi hos fullbårne (gestasjonsalder $\geq 37$ fullgåtte uker) og premature barn (gestasjonsalder $<37$ uker) (modifisert etter "The Hillingdon Hospital Bilirubin Chart", England). Den midtre kurven angir indikasjonsgrensen for transcutan bilirubin index som indiserer blodprøvetagning hos fullbårne barn.

Tabell 1. Data for behandling av hyperbilirubinemi hos nyfødte 1991-93 og 1994-95.

\begin{tabular}{lrrrrrr}
\hline & \multicolumn{2}{c}{$1991-93$} & & \multicolumn{2}{c}{$1994-95$} & \\
\cline { 2 - 3 } & \multicolumn{1}{c}{$\mathrm{n}$} & $\%$ & & $\mathrm{n}$ & $\%$ & \\
\hline Levende fødte (totalt) & 6954 & & & 4646 & & \\
Antall fødte $<37$ uker & 310 & 4,5 & & 275 & 5,9 & 0,0004 \\
Lysbehandlet (totalt) & 481 & 6,9 & & 254 & 5,5 & 0,002 \\
Lysbehandlet fysiologisk ikterus & 302 & 4,3 & & 76 & 1,6 & 0,0001 \\
Lysbehandlet prematuritetsikterus & 140 & 2,0 & & 147 & 3,2 & 0,0001 \\
\% av barn < 37 uker lysbehandlet & & 45,2 & & & 53,1 & 0,04 \\
Lysbehandlet for immunisering & 39 & 0,6 & & 31 & 0,7 & 0,47 \\
Utskiftningstransfusjon & 15 & 0,2 & & 3 & 0,06 & 0,04 \\
\hline
\end{tabular}




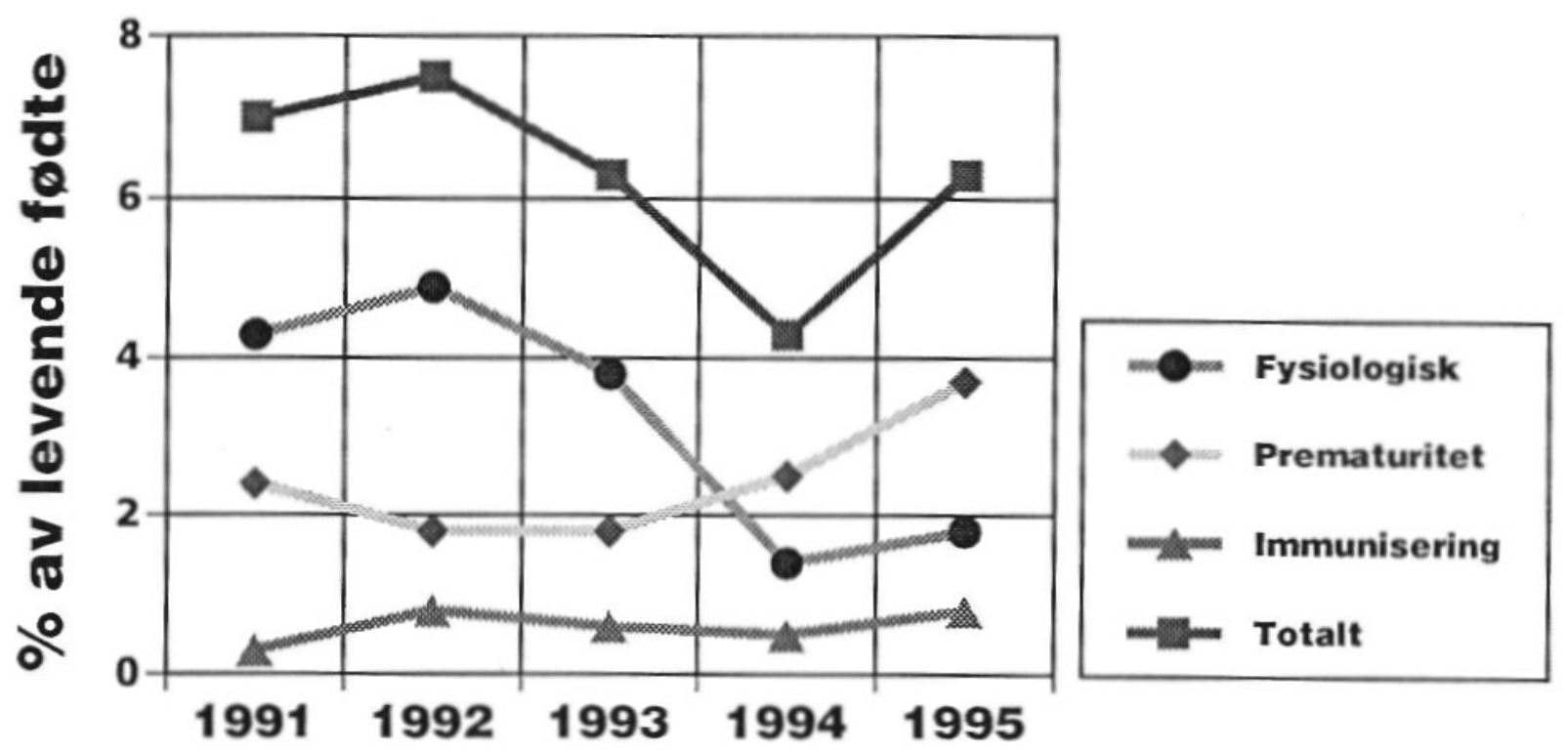

Figur 3. Prevalens av lysbehandling for fysiologisk ikterus, prematuritetshyperbilirubinemi og blodgruppeimmunisering blant levende fødte i 5-års perioden 1991-95.

95, og demonstrerer det markerte fallet i lysbehandlingsinsidens for fysiologisk ikterus og stigningen $\mathrm{i}$ andelen behandlet for prematuritetsikterus.

\section{DisKuSJON}

\section{Hovedfunn}

Etablering av nye retningslinjer for lysbehandling av hyperbilirubinemi ved vårt sykehus (bilirubinskjema brukt ved Hillingdon sykehus, England) har medført et signifikant fall i prevalensen av barn som behandles for hyperbilirubinemi totalt, og spesielt $\mathrm{i}$ andelen behandlet for fysiologisk ikterus (redusert med hele $63 \%$ ). Dette har medført en viss ressurssparing. Med bakgrunn i internasjonal forskning (9-11) er det grunn til å tro at rutineskiftet også har betydd gevinster i form av mindre forstyrrelse av sensitive psykologiske prosesser i tilknytningen mellom mor og barn, og reduksjon av biologiske bivirkninger (selv om disse trolig er relativt ufarlige) av lysbehandlingen hos ellers friske fullbårne barn.

\section{Lysbehandling av fullbårne barn}

Det diskuteres idag om fysiologisk ikterus medfører noen reell risiko for utvikling av bilirubinencephalopathi (kjerneikterus) hvis ikke andre risikofaktorer og sykdomstilstander er til stede $(3,4,7,8)$. Klassisk kjerneikterus hos fullbårne barn er en meget sjelden tilstand, og først og fremst beskrevet ved serumbilirubinverdier på over $600 \mu \mathrm{mol} / 1(2,7)$. Tilstanden har oftest vært assosiert med ikke erkjent blodgruppeimmunisering, annen hemolytisk sykdom, infeksjoner og hyperton dehydrering $(2,15,16)$. Barn i grenseområdet mot prematuritet (gestasjonsalder 37-38 uker) synes å være en spesiell risikogruppe (2). I en stor prospektiv amerikansk undersøkelse hvor 41324 barn med fødselsvekt $>2,5 \mathrm{~kg}$ ble fulgt til 7-års alder ble det ikke funnet noen korrelasjon mellom bilirubinnivået og IQ, alvorlige nevrologiske følgetilstander eller hørselstap (8). Barn med bilirubinnivåer $>342 \mu \mathrm{mol} / 1$ hadde ikke økt risiko for disse tilstandene i forhold til barn med lavere bilirubinnivåer. Mot denne bakgrunn kan det synes det riktig å innføre "a kinder, gentler approach," og intervenere med lysbehandling (eller evt. utskiftningstransfusjon) for å holde bilirubinverdiene under 400-500 $\mu \mathrm{mol} / \mathrm{l}$ (17). Ved en slik strategi kan overbehandling holdes på et akseptabelt nivå med bibehold av minimal risiko for kjerneikterus.

Idag diskuteres bilirubinets potensielt nyttige effekter for organismen, bl.a. antioksydativ effekt (18). Høyere bilirubinverdier ved morsmelkernæring (19) og konservering av bilirubin utskilt til tarmen gjennom enzymatisk dekonjugering og reabsorpsjon (enterohepatisk sirkulasjon) er indirekte indikasjoner på at bilirubin kan ha nyttige biologiske effekter.

Det er viktig å være klar over at hyperbilirubinemi kan være et symptom på en del sjeldne grunnlidelser (metabolske sykdommer, ikke-immunologisk betingete hemolytiske sykdommer m.m.). Avvik i klinikk og laboratorieresultater kan indikere dette, og nødvendiggjøre en bredere laboratoriemessig utredning.

De senere årene har det vært en trend i retning av kortere liggetider i sykehus etter fødsel. Dette har medvirket til økende frekvens av reinnleggelser for hyperbilirubinemi (20), som i flere materialer er vist å være den hyppigste årsak til reinnleggelse de første leveukene $(20,21)$. Det er derfor viktig å etablere et 
oppfølgingssystem utenfor sykehus som ivaretar dette aspektet (informasjon til foreldre, opplæring av primærhelsetjenesten). Liberal lysbehandling av ellers friske, fullbårne barn er ingen rasjonell strategi for å forebygge dette problemet.

\section{Lysbehandling av premature barn}

Det vitenskapelige grunnlaget for lysbehandling av premature ut fra bestemte bilirubinnivåer er svakt. Prematurt fødte barn representer en heterogen gruppe med ulike sykdomstilstander knyttet til bl.a. organumodenhet. Slike tilstander (f.eks. lungesvikt med hypoksi, hjerneblødninger) kan i seg selv medføre cerebrale skader hos barnet. Høye bilirubinverdier kan i slike sammenhenger muligens være en tilleggsrisiko $(22,23)$. Det har også vært antatt at premature er sensitive for bilirubintoksisitet, og at skader kan oppstå ved lavere serumnivåer enn hos fullbårne barn. Nyere undersøkelser stiller imidlertid spørsmål ved dette, både ut fra kliniske oppfølgingsstudier og autopsiundersøkelser (23-25). I praktisk klinisk arbeid må indikasjonene for lysbehandling av premature stilles ut fra serum-bilirubinnivået kombinert med en totalvurdering av barnets tilstand (gestasjonsalder, assosierte risikofaktorer og sykdom). Det kan være riktig å ha en liberal holdning til lysbehandling av disse barna, som oftest overflyttes til en "neonatal special care unit" eller "intensive care unit" for overvåkning og behandling. For prematurt fødte (uansett vekt og gestasjonsalder) opererer skjemaet som nå brukes i vår avdeling med én kurve som angir indikasjonen for lysbehandling (figur 2). Denne grensen er de første 3-4 levedagene lavere enn i det tidligere anvendte skjema. Dette har medført at andelen prematurt fødte barn som lysbehandles har økt med $17,5 \%$ (fra $45,2 \%$ i kohorten født $1991-93$ til 53,1\% i 1994-95). I den grad premature ansees å ha en spesiell risiko for bilirubinencephalopathi kan dette være en riktig strategi. Indikasjonskurven for lysbehandling av premature anvendes også veiledende for fullbårne barn med sykdom som kan medføre en skadet blodhjernebarriære (asfyksi, sepsis, meningitt etc.) og derved større risiko for bilirubinskader.

\section{Utskiftningstransfusjon}

Bilirubinskjemaet fra Hillingdon sykehus opererer med høyere bilirubinnivåer for utskiftningstransfusjon både for premature og fullbårne barn enn det gamle. Utskiftningstransfusjon er et inngrep som ikke er uten risiko, og både dødsfall og cerebrale skader er beskrevet i kjølvannet av cardiosirkulatoriske komplikasjoner. Risiko foreligger også for overføring av infeksiøse agens, og for immunologiske reaksjoner. Det er derfor riktig å ha relativt strenge indikasjoner for dette inngrepet. I vårt materiale har insidensen av utskiftningstransfusjon falt betydelig etter innføringen av de nye retningslinjene. Hvor utskiftningstransfusjon har vært gjennomført og ellers ved påvist blodgruppe- immunisering (positiv Coombs' test) uten behov for utskiftningstransfusjon følges barna opp med hemoglobinmålinger (veiledende ved 3 og 6 ukers alder). Det har i det aktuelle tidsrom ikke vært nødvendig med oppfølgende blodtransfusjoner pga. anemiutvikling.

\section{Praktisk anvendelse}

Det nye bilirubinskjemaet har fungert meget tilfredsstillende ved vårt sykehus. Skjemaet er enkelt å bruke, og kombinert med non-invasiv bilirubinovervåking (transcutan bilirubin index) er behovet for blodprøvetagning for bilirubinbestemmelse blitt redusert. Dette er også erfaringene fra andre avdelinger (Anderssen S-H, Østfold sentralsykehus, avd. Fredrikstad, upubliserte data). Etter modell fra barneavdelingen, Østfold sentralsykehus (Anderssen S-H, upubliserte data) har vi fra 1996 lagt inn en arbitrær kurve for transcutan bilirubin index som sikkerhetsmargin overfor spredningen i serum-bilirubinnivået ved transcutane målinger (figur 2). Det skal presiseres at transcutan bilirubinindex er en screeningmetode for diagnostikk av fysiologisk hyperbilirubinemi hos friske fullbåren barn i barselavdelinger, og ikke bør benyttes hos premature eller barn innlagt i neonatalavdelinger for ulike sykdomstilstander (26). Hos disse må serumbilirubinmålinger skje ved blodprøvetagning.

\section{Nasjonale retningslinjer}

I internasjonal sammenheng er det betydelige variasjoner $\mathrm{i}$ indikasjonene for behandling av hyperbilirubinemi med fototerapi og utskiftningstransfusjon (27). Det nye bilirubinskjemaet som anvendes i vår avdeling faller godt innenfor det som i dag er internasjonale standarder, og er f.eks. for fullbårne barn mer aggressivt $i$ indikasjonene for lysbehandling enn retningslinjene anbefalt av American Academy of Paediatrics (28). I lys av nyere internasjonal forskning er det behov for en ny diskusjon i fagmiljøet om retningslinjene for behandling av hyperbilirubinemi hos nyfødte i Norge med tanke på nasjonal konsensus. De indikasjonene som tidligere har vært brukt, representerer empiri og ikke "evidence based medicine" (29). Det burde derfor etisk sett ikke være betenkelig å justere disse til internasjonalt autoriserte standarder som også er empirisk begrunnet. Dette kan tvert imot være etisk vel begrunnet med bakgrunn i det klassiske Hippokratiske prinsippet om at "behandlingen skal være til nytte for pasienten, og ikke til skade." Unødig lysbehandling av friske fullbårne barn med ikterus, med mulighet for uheldige psykologiske og biologiske effekter, kan reduseres betydelig med de moderate justeringer som er pekt på i denne artikkelen. Disse retningslinjene har ved vår avdeling har også medført ressurssparing. På landsbasis vil innføring av slike retningslinjer bety at 1000-2000 barn som hvert år lysbehandles for fysiologisk ikterus kunne unngå slik behandling. 


\section{REFERANSER}

1. Maisels MJ. Jaundice in the newborns - re-defining physiological jaundice. West J Med 1988; $149: 451$.

2. Maisels MJ, Newman TB. Kernicterus in otherwise healthy, breast-fed term newborns. Pediatrics 1995; 96: 730-3.

3. Newman TB, Maisels MJ. Does hyperbilirubinemia damage the brain of healthy full-term infants? Clin Perinatol 1990; 17: 331-58.

4. Dodd KL. Neonatal jaundice - a lighter touch. Arch Dis Child 1993; 68: 529-33.

5. Funato M, Tamai H, Shimada S, Nakamura H. Vigintiphobia, unbound bilirubin, and auditory brainstem response. Pediatrics 1994; 93: 50-3.

6. Newman TB, Maisels MJ. Evaluation and treatment of jaundice in the term newborn: a kinder, gentler approach. Pediatrics 1992; 89: 809-18.

7. Hey E. Neonatal jaundice - how much do we really know? MIDIRS Midwifery Digest 1995; 5: 4-8.

8. Newman TB, Klebanoff MA. Neonatal hyperbilirubinemia and long-term outcome: another look at the collaborative perinatal project. Pediatrics 1993; 92: 651-7.

9. Klaus MH, Kennell JH. Maternal-infant bonding. Saint Louis: CV Mosby Company, 1976.

10. Bratlid D. Fototerapi ved neonatal hyperbilirubinemi. Tidsskr Nor Laegeforen 1986; 106: 1830-3.

11. Christensen T, Kinn G, Granli T, Amundsen I. Cells, bilirubin and light: formation of bilirubin photoproducts and cellular damage at defined wavelengths. Acta Pcediatr 1994; 83: 7-12.

12. Yamanouchi I, Yamauchi Y, Igarashi I. Transcutaneous bilirubinometry: preliminary studies of noninvasive transcutaneous bilirubin meter in the Okayama national hospital. Pediatrics 1980; 65: 195-202.

13. Meberg A, Wefring KW. Non-invasiv måling av serumbilirubin hos nyfødte. Tidsskr Nor Laegeforen 1984; 104: $970-2$.

14. Finlay HVL, Tucker SM. Neonatal plasma bilirubin chart. Arch Dis Child 1978; 53: 90-1.

15. Penn AA, Enzmann DR, Hahn JS, Stevenson DK. Kernicterus in a full term infant. Pediatrics 1994; 93: 1003-6.

16. Estmann Christensen A. Kernicterus hos et maturt barn. Ugeskr loeger 1996; 159: 1230-1.

17. Newman TB, Maisels JM. Evaluation and treatment of jaundice in the term newborn: a kinder, gentler approach. Pediatrics 1992; 89: 809-18.

18. McDonagh AF. Is bilirubin good for you? Clin Perinatol 1990; 17: 359-69.

19. Maisels MJ, Gifford K. Normal serum bilirubin levels in the newborn and the effect of breast-feeding. Pediatrics 1986; 78: 837-43.

20. Lee, K-S, Perlman M, Ballantyne M, Elliott I, To T. Association between duration of neonatal hospital stay and readmission rate. J Pediatr 1995; 127: 758-66.

21. Soskolne EI, Schumacher R, Fyock C, Young ML, Schork A. The effect of early discharge and other factors on readmission rates of newborns. Arch Pediatr Adolesc Med 1996; 150: 373-9.

22. van de Bor M, van Zeben-van der Aa TM, Verloove-Vanhorick SP, Brand R, Ruys JH. Hyperbilirubinemia in preterm infants and neurodevelopmental outcome at 2 years of age: results of a national collaborative survey. Pediatrics 1989; 83: 915-20.

23. Gartner LM, Catz CS, Yaffe SJ. Neonatal bilirubin workshop. Pediatrics 1994; 94: 537-9.

24. Watchko JF, Oski FA. Kernicterus in preterm newborns: past, present, and future. Pediatrics 1992; 90: 70715.

25. Watchko JF, Claassen D. Kernicterus in premature infants: current prevalence and relationship to NICHD phototherapy study exchange criteria. Pediatrics 1994; 93: 996-9.

26. Knudsen A, Ebbesen F. Transcutaneous bilirubinometry in neonatal intensive care units. Arch Dis Child 1996; 75: F53-F56.

27. Ruud Hansen TW. Behandling av icterus hos nyfødte. Norske retningslinjer i internasjonalt perspektiv. Tidsskr Nor Loegeforen 1996; 116: 3215-8.

28. American Academy of Pediatrics. Provisional committee for quality improvement and subcommittee on hyperbilirubinemia. Practice parameter: management of hyperbilirubinemia in the healthy term newborn. Pediatrics 1994; 94: 558-65.

29. Bratlid D. Lysbehandling av nyfødte med hyperbilirubinemi. Tidsskr Nor Lageforen 1996; 116: 3207-8. 